5. Levickij, I.N. (1976). Obshhie cherty razlichnyh sposobov mehanicheskoj obrabotki steblevyh materialov [General features of various methods of machining stems materials]. Izv. vuzov. Tehnologija tekstil'noj promyshlennosti - News of universities. Technology of textile industry, 1, 41-43.

6. Ivanov, M.N. (1976). Machine parts.(3d ed). Moscow: „Vyssh. shkola”.

Alla Lisikh, PhD. tech. sci.

Pervomasky branch of the Mykolaiv university of shipbuilding of the name of admiral Makarov, Pervomaysk, Ukraine

\title{
Development and Calculation of the Kinematic Circuit of the Mechanism for Reception of a Short Flax Fiber
}

The article is devoted to the calculation of the kinematic scheme of the nutrient-quenching and parallelization mechanism, which carries out the process of preparation of flax fiber scrap waste for further more efficient mechanical processing in order to obtain a qualitative short fiber.

According to the kinematic scheme, the transfer of movement to individual organs of the experimental setup is carried out by belt and gear gears. The rotation frequency of the individual operating mechanisms of the equipment is determined by the kinematic scheme using gear ratios. The gear ratio is equal to the ratio of the angular velocities or rotation frequencies of the bodies connected by transmission. Determination of the dependence of the degree of parallelization of short flax fiber was carried out in an experimental setup consisting of a nutritional-drying mechanism, a chopping machine with five pairs of finely chopped milling rolls and a parallelizer.

A research experimental setup has been developed to produce a short linen fiber of improved quality from scrap waste. The calculation of the kinematic scheme and the speed parameters of the working organs of the experimental setup is carried out.

kinematic scheme, parallelization mechanism, coefficient of thinning, gear ratio

Одержано (Received) 18.05.2018

УДК 631.894:879.4

С.І. Павленко, доц., канд. техн. наук, ст. наук. співр.

Національний університет біоресурсів $і$ природокористування України, м. Київ, Україна, E-mail: si.pavlenko17@gmail.com

\section{Виробничі випробування технології механізованого компостування органічних відходів з використанням аератора-змішувача}

Проведений системний аналіз поводження з органічними відходами, існуючий в господарстві на фермі великої рогатої худоби стійлового утримання. Результати аналізу узагальнені у вигляді таблиці, що розглядає технологічний процес, операції та склад технічних засобів та матеріалів і значення показників операції. Сформовані робочі гіпотези по покращенню технології поводження $з$ органічними відходами на основі вдосконалення технологічних прийомів циклу, яким необхідно повести експериментальну перевірку:

- формування буртів при суцільному складуванні гноєвих сумішей за рахунок створення проходів шириною до 2-3 м в середовищі сировини вологістю до 75 \% за допомогою бульдозера або іншого технічного засобу;

- формування буртів при вивантаженні гноєкомпостної суміші на майданчик при транспортуванні сировини самоскидним тракторним причепом або розкидачем органічних добрив, що агрегатуються з трактором МТ3-80;

- укрупнення буртів з використанням бульдозера;

- покращення аерації за рахунок використання аератора-змішувача, конструкції ІМТ НААН України.

(C) С.І. Павленко, 2018 
Розроблений вдосконалений технологічний i технічний регламенти механізованого компостування. Визначені геометричні параметри буртів, їх щільність, маса. Проведені результати випробування технічних засобів: бульдозера, аератора-змішувача згідно стандартним методикам.

виробничі випробування, технологія, компост, прискорене компостування, аератор-змішувач, формування бурта

С.И. Павленко, доц., канд. техн. наук, ст. наук. сотр.

Национальный университет биоресурсов и природопользования Украины,, г. Киев, Украина

Производственные испытания технологиимеханизированного компостирования органических отходов с использованием аэратора-смесителя

Проведенный системный анализ поведения с органическими отходами, существующий в хозяйстве на ферме крупного рогатого скота стойлового содержания. Результаты анализа обобщены в виде таблицы, рассматривает технологический процесс, операции и состав технических средств и материалов и значения показателей операции. Сформированы рабочие гипотезы по улучшению технологии обращения с органическими отходами на основе совершенствования технологических приемов цикла, которым необходимо повести экспериментальную проверку:

- формирование буртов при сплошном складировании гноя смесей за счет создания проходов шириной до 2-3 м в среде сырья влажностью до 75\% с помощью бульдозера или другого технического средства;

- формирование буртов при выгрузке гноекомпостнои смеси на площадку при транспортировке сырья самосвальным тракторным прицепом или разбрасывателем органических удобрений, которые агрегатируются с трактором МТЗ-80;

- укрупнение буртов с использованием бульдозера; Украины.

- улучшение аэрации за счет использования аэратора-смесителя, конструкции ИМТ НААН

Разработан усовершенствованный технологический и технический регламенты механизированного компостирования. Определены геометрические параметры буртов, их плотность, масса. Проведенные результаты испытания технических средств: бульдозера, аэратора-смесителя согласно стандартным методикам.

производственные испытания, технология, компост, ускоренное компостирование, аэраторсмеситель, формирование бурта

Постановка проблеми. В умовах реального господарствата вреальних умовах експлуатації тієї чи іншої машини часто виникають задачі щодо вдосконалення процесів поводження 3 органічними відходами тваринництва i рослинництва. Рушійними чинниками слугують: необхідність покращення стану оточуючого середовища, підвищення ефективності органічних добрив, їх кількості, хімічного складу, раціональне використання технічних засобів і земельних угідь, що в кінцевому результаті приводить до збільшення родючості грунтів, зменшення витрат на мінеральні добрива і хімічні препарати, можливості виробництва органічної продукції, ресурсозбереженню, диверсифікації продукції агропідприємства.

Нормативні правила «Проектуванні тваринницьких приміщень і комплексів» передбачають використання сучасних технологічних та технічних рішень по системах видалення та переробки гною $[1,2,3]$. В той же час в Україні діють тваринницькі ферми і комплекси, що збудовані за вимогами ранніх періодів, які теж вимагають вдосконалення, відповідності і адаптації нових технологій та технічних засобів. Один із варіантів - застосування біоконверсних методів та сучасних технічних засобів для їх виконання.

Аналіз останніх досліджень і публікацій. Біоконверсні технології переробки органічних відходів тваринництва і рослинництва - широко розповсюджені методи, кошторис яких економічно доступний $[4,5]$. Вони базуються на аеробних або анаеробних способах розкладання органічної речовини - в присутності кисню в першому випадку і без нього в другому. Можлива комбінація способів. Природні аераційні процеси відбуваються постійно і, в залежності від умов організації термічних 
режимів, проходять в терміни від двох неділь до 24 місяців. Формуванню умов інтенсивних аеробних процесів та дослідженню технічних засобів для забезпечення механізованих циклів переробки розглядаються в ряді наукових праць $[6,7]$.

Серед способів інтенсифікації аеробних процесів можливо виділити: вдосконалення природної аерації, проведення механічної аерації або примусової подачі повітря в середовище гноєкомностної суміші. Основна мета заходів - покращення кисневого забезпечення мікроорганізмів, які при масовому їх збільшенню активізують процеси життєдіяльності, що приводить до підвищення температурних режимів в сировині за необхідного складу і фізичного стану суміші.

Природна аерація відбувається за рахунок поглинання кисню, що заповнює простір між частками матеріалу сировини. Чим краще організований процес доступу кисню, тим швидше i ефективніше проходить компостування - мінералізація. Реалізація процесів залежить від раціонального хімічного i механічного складу гноєкомпостних сумішей, організації і складування сировини - в буртах або суцільно. Такий спосіб належить до пасивних дієвих методів 3 низькими фінансовими затратами, але терміни дозрівання більше 6 місяців.

Активні методи аерації - механічне та примусове нагнітання - фінансово i організаційно складніше, але терміни компостування набагато менші від 14 днів до 2-4 місяців в залежності від складу суміші. Аерація проводиться технічними засобами ротоційно-фрезерними робочими органами, що використовуються в конструкціях розкидачів органічних добрив, спеціальних машинах, що одержали назву аератори змішувачі, навантажувачах безперервної дії гною. Взаємодія робочого органу 3 сировиною забезпечує подрібнення, змішування, вивільнення парів води, вуглецевого газу та суміші, заповненню приросту між частками киснем, а вцілому, активному процесу окислення, що приводить до необхідного результату[8]. Технічні засоби, активно розробляються та вдосконалюються $[9,10]$.

Примусова аерація проводиться на майданчиках або спорудах, де через отвори, канали, нагнітається повітря в сировину - гноєкомпостну суміш, що розташовується в межах діючого обладнання. Терміни обробітку - від 20 до 30 діб. Необхідність побудови спеціальних майданчиків і споруд, відносно невеликі обсяги обробітку $є$ суттєвими недоліками цього методу, але широко використовуються для одержання товарної продукції: компостів для вирощування грибів, органо-мінеральних добрив, тощо.

Процеси механізованого компостування постійно вдосконалюються. В питаннях приготування субстратів при різних характеристиках сировини, використовуваних технічних засобів, організації виробництва. Дослідження, аналіз практичного досвіду, результативність має актуальне науково-практичне значення і доповнення.

Постановка завдання. Метою дослідження $\epsilon$ подальший розвиток раціонального використання технічних засобів в механізованих процесах твердофазного компостування.

Основні задачі дослідження:

- встановлення раціональної послідовності технологічних операцій і складу технічних засобів;

- дослідження змін фізико-механічних властивостей в процесі біоферментації та механічної обробки;

- встановлення зміни параметрів компостних сумішей, готового компосту, термінів компостування, техніко-економічних показників роботи засобів механізації.

Виклад основного матеріалу. Сировина, що використовувалась для дослідження: 
- підстилковий гній великої рогатої худоби щоденного видалення, вологістю до $80 \%$;

- підстилковий гній великої рогатої худоби 3 вигульних майданчиків, вологістю $60-65 \%$;

- підстилковий матеріал: солома злакових культур, відходи силосу.

Раціональна послідовність технологічних операцій і використання технічних засобів проводилась на основі аналізу виконання технологічного процесу біотермічного компостування, якості отриманої гноє-компостної суміші, аналізу техніко-економічних показників, одержаних в процесі експериментів. Фізико-хімічні властивості гноєкомпостних сумішей та готових продуктів визначали стандартними методами згідно ГОСТ 26712-82, ГОСТ 26718-82 «Удобренияорганические». Аналізи проводили за участю фахівців Дніпропетровської філії Державної установи «Держгрунтохорона». Кінетика біотермічного процесу оцінювалась шляхом вимірювання температури в 4-6 точках попереднього і повздовжнього напрямку штанговим термометром.

В якості технічного засобу використовувався аератор-змішувач конструкції ІМТУААН України. Проведення експериментальних випробувань технічних засобів проводилось згідно стандартних методик.

Умови проведення досліджень. Операційну технологію поводження 3 органічними відходами тваринництва і рослинництва в господарстві (табл. 1), а блок схема на рис 1. і є практично типовим для тваринницьких підрозділів великої рогатої худоби на 200-600 голів основного поголів'я. Видалення та навантаження гною приміщень - скребковий та похилий конвеєр ТСН-3. Технічне забезпечення процесів управління відходами 3 бульдозерного навісного обладнання складається 3 бульдозерного навісного обладнання до трактора T-74, навантажувача «Карпатець», 3 грейферним захватом, трактором МТЗ-80 та самоскидним тракторним причепом 2ПТС-4. Складування і зберігання сировини проводиться на протязі 18-24 місяців на тимчасовому грунтовому майданчику зберігання 3 суцільним укладанням без додаткових обробіток. За період зберігання підстилковий гній розкладається до маси чорного кольору розсипчастої структури, що використовується, в якості органічних добрив.

Таблиця 1 - Операційна механізована технологіяповодження 3 органічними відходами, прийнята в господарстві

\begin{tabular}{|c|c|c|c|c|}
\hline $\begin{array}{l}\text { № } \\
\text { П.п. }\end{array}$ & $\begin{array}{l}\text { Технологічний } \\
\text { процес }\end{array}$ & $\begin{array}{l}\text { Шифр } \\
\text { операції }\end{array}$ & Операція & $\begin{array}{l}\text { Склад технічних засобів та } \\
\text { параметри і значення показників } \\
\text { операції }\end{array}$ \\
\hline & & 011 & $\begin{array}{l}\text { Прибирання } \\
\text { стійла }\end{array}$ & $\begin{array}{l}\text { Вручну. Періодичність: до } 4 \text { разів } \\
\text { на добу }\end{array}$ \\
\hline 01 & Видалення гною & 012 & $\begin{array}{l}\text { Видалення } \\
\text { гною } \\
\text { відкритих } \\
\text { каналів }\end{array}$ & $\begin{array}{l}\text { Скребковий конвейер типу ТСН- } \\
3,0 \text { Б. Підстилковий гній } \\
\text { вологістю до } 80 \% \text {. Обсяг робіт } \\
\text { до } 12 \text { m/добу. Кількість } \\
\text { підстилкового матерілу-соломи } \\
1-3 \quad \text { кг/голову. } \\
\text { Продуктивність: } 4,5-7,0 \text { т/годн. }\end{array}$ \\
\hline 02 & $\begin{array}{l}\text { Вивантаження } \\
\text { гною }\end{array}$ & 021 & $\begin{array}{l}\text { Щоденне } \\
\text { вивантаження } \\
\text { гною } \\
\text { приміщення }\end{array}$ & $\begin{array}{lcr}\text { Похилий } & \text { скребковий } & \text { конвеєр } \\
\text { TСН-3Б. } & \text { Вологість } \\
\text { підстилкового } & \text { гною } & 80-85 \% . \\
\text { Продуктивність до 10т/г }\end{array}$ \\
\hline
\end{tabular}




\begin{tabular}{|c|c|c|c|c|}
\hline $\begin{array}{l}\text { № } \\
\text { п.п. }\end{array}$ & $\begin{array}{l}\text { Технологічний } \\
\text { процес }\end{array}$ & $\begin{array}{l}\text { Шифр } \\
\text { операції }\end{array}$ & Операція & $\begin{array}{l}\text { Склад технічних засобів та } \\
\text { параметри і значення показників } \\
\text { операції }\end{array}$ \\
\hline & & 022 & $\begin{array}{l}\text { Вивантаження } \\
\text { гною } \\
\text { вигульних } \\
\text { майданчиків }\end{array}$ & $\begin{array}{l}\text { Навантажувач «Карпатець» } 3 \\
\text { грейферним захватом. Вологість } \\
\text { підстилкового гною: до 75-78. } \\
\text { Продуктивність: 15-20т/год. }\end{array}$ \\
\hline \multirow[t]{3}{*}{03} & Транспортування & 031 & $\begin{array}{l}\text { Транспортуван } \\
\text { ня гною } \quad 3 \\
\text { вигульних } \\
\text { майданчиків } \\
\end{array}$ & $\begin{array}{l}\text { Трактор } \quad \text { МТ3-80+1ПТС-4. } \\
\text { Дальність маршруту до } 0,5 \text { км. }\end{array}$ \\
\hline & & 032 & $\begin{array}{l}\text { Транспортуван } \\
\text { ня гною при } \\
\text { щоденному } \\
\text { вивантаженні }\end{array}$ & $\begin{array}{l}\text { Трактор МТ3-80 }+2 \text { МТС }-4 . \\
\text { Дальність маршруту до } 0,5 \text { км }\end{array}$ \\
\hline & & $\begin{array}{l}0321 \\
0311\end{array}$ & Розвантаження & $\begin{array}{l}\text { Суцільне складування сировини. } \\
\text { Висота бурту до } 1,0 \mathrm{M}\end{array}$ \\
\hline 04 & Карантування & & & $\begin{array}{l}\text { Витримка на } \\
\text { тимчасоводанчику } \\
\text { тисо зберігання 7-10днів }\end{array}$ \\
\hline 05 & $\begin{array}{l}\text { Складування } \quad \text { i } \\
\text { зберігання }\end{array}$ & & & $\begin{array}{lc}\text { Бульдозерне } & \text { обладнання } \\
\text { трактора T-74. Зберігання від } 18 \\
\text { до } 24 \text { місяців в залежності від } \\
\text { термінів } \\
\text { майданчик. } & \text { постачанням Періодичне } \\
\text { підгортання } & 3-4 \text { рази на рік до } \\
\text { створення } & \text { суцільного } \\
\text { середовища висотою } 1-1,2 \mathrm{M} .\end{array}$ \\
\hline 06 & $\begin{array}{l}\text { Контроль } \quad \text { за } \\
\text { процесами } \\
\text { компостування }\end{array}$ & & & $\begin{array}{l}\text { Tемпературні режим від } 12^{\circ} \mathrm{C} \text { до } \\
30^{\circ} \mathrm{C} \text {, на глибині } 0,5-0,6 \mathrm{~m} \text { від } \\
\text { поверхні. Суттєве значення має } \\
\text { температура,оточуючого } \\
\text { середовища. Поверхневий шар } \\
\text { сировини на глибину до } 20-30 \mathrm{~cm} \\
\text { пересихає і } \text { заважає } \\
\text { проникненню кисню до нижніх } \\
\text { шарів. Вологість нижніх шарів } \\
\text { гноєсумішей на протязі літнього } \\
\text { сезону складає 72-76\%. Процес } \\
\text { зволоження відбувається під } \\
\text { дією атмосферних опадів. }\end{array}$ \\
\hline 07 & $\begin{array}{l}\text { Готовність } \\
\text { добрив }\end{array}$ & & & За 18-24 місяці. \\
\hline \multirow[b]{2}{*}{08} & \multirow{2}{*}{$\begin{array}{l}\text { Внесення } \\
\text { добрив }\end{array}$} & 081 & Навантаження & $\begin{array}{ll}\text { Навантажувач } & \text { «Карпатець». } \\
\text { Продуктивність } & 20-25,0 \mathrm{~T} / \text { год. } \\
\text { Вологість сировини } 55-65 \%\end{array}$ \\
\hline & & 082 & $\begin{array}{l}\text { Транспортуван } \\
\text { ня і внесення }\end{array}$ & $\begin{array}{l}\text { Розкидач ПРТ-7(ПРТ-10) } \\
\text { МТЗ-80. Дальність переміщення } \\
\text { до } 5 \text { км. Норми внесення - згідно } \\
\text { агровимог. }\end{array}$ \\
\hline
\end{tabular}

Методика проведення випробувань механізованої технології. Сформовані робочі гіпотези по покращенню технології поводження з органічними відходами на 
основі вдосконалення технологічних прийомів циклу, яким необхідно провести експериментну перевірку:

- формування буртів при суцільному складуванні гноєвих сумішей на основі створення проходів шириною до 2-3 м в середовищі сировини за допомогою бульдозера або іншого технічного засобу;

- формування буртів при вивантаженні гноєкомпостної суміші на майданчик при транспортуванні сировини самоскидним тракторним причепом або розкидачем органічних добрив, що агрегатуються з трактором МТ3-80;

- укрупнення буртів з використанням бульдозера за необхідністю;

- покращення аерації за рахунок використання аератора-змішувача, конструкції інституту механізації тваринництва Національної Академії Аграрних Наук (IMT НААН) України [10, 11].

На основі технічних засобів запропонована модернізована механізована технологія поводження із органічними відходами в умовах господарства табл.2, експериментальна перевірка якої проводилась в період з червня по серпень 2015 року.

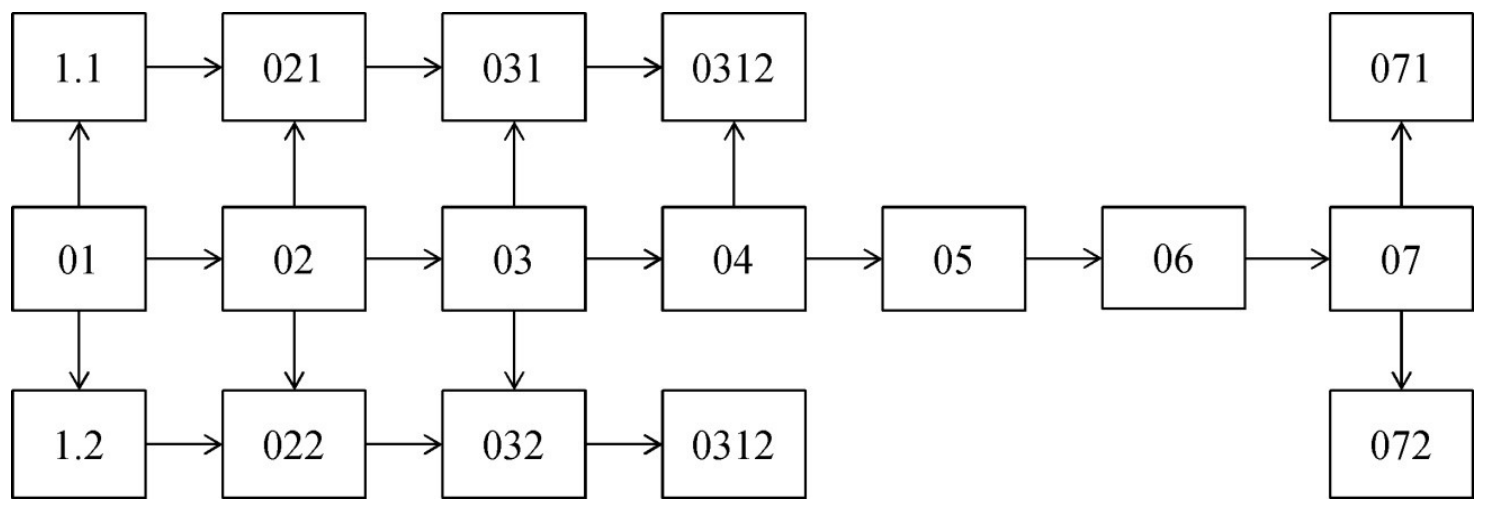

Рисунок 1 - Блок схема процесу одержання і внесення органічних добрив в господарстві

Таблиця 2 - Вдосконаленні технологічні операції поводження з органічними відходами умов господарства (операції 011-032 аналогічні проведеними в табл. 1)

\begin{tabular}{|c|c|c|c|c|}
\hline $\begin{array}{l}\text { № } \\
\text { п.п. }\end{array}$ & $\begin{array}{l}\text { Технологічний } \\
\text { процес }\end{array}$ & $\begin{array}{c}\text { Шифр } \\
\text { операції }\end{array}$ & Операція & $\begin{array}{c}\text { Склад технічних засобів та } \\
\text { параметри і значення показників } \\
\text { операції }\end{array}$ \\
\hline 03 & & 0321 & $\begin{array}{l}\text { Розвантаження } 3 \\
\text { формуванням } \\
\text { бурту і проходів } \\
\text { між ними }\end{array}$ & $\begin{array}{l}\text { Бурти з параметрами ширина до } \\
2,5 \mathrm{~m} \text {, довжина - до } 50 \mathrm{M} \text {, висота } \\
\text { до } 1,2 \mathrm{~m}\end{array}$ \\
\hline 04 & Карантування & & & \\
\hline \multirow[t]{3}{*}{04} & \multirow[t]{3}{*}{$\begin{array}{l}\text { Формування } \\
\text { гноєкомпостної } \\
\text { суміші }\end{array}$} & 041 & $\begin{array}{l}\text { Внесення волого- } \\
\text { поглинаючих } \\
\text { матеріалів }\end{array}$ & \\
\hline & & 0411 & $\begin{array}{l}\text { Навантаження } \\
\text { соломи }\end{array}$ & \\
\hline & & $\begin{array}{l}0412 \\
0413\end{array}$ & $\begin{array}{l}\text { Tранспортування } \\
\text { та } \quad \text { внесення } \\
\text { соломи }\end{array}$ & Трактор МТ3-80+КТУ-10 \\
\hline
\end{tabular}




\begin{tabular}{|c|c|c|c|c|}
\hline $\begin{array}{l}\text { № } \\
\text { п.п. }\end{array}$ & $\begin{array}{l}\text { Технологічний } \\
\text { процес }\end{array}$ & $\begin{array}{l}\text { Шифр } \\
\text { операції }\end{array}$ & Операція & $\begin{array}{c}\text { Склад технічних засобів та } \\
\text { параметри і значення показників } \\
\text { операції } \\
\end{array}$ \\
\hline & & 042 & $\begin{array}{l}\text { Укрупнення } \\
\text { буртів }\end{array}$ & $\begin{array}{l}\text { Бульдозерне обладнання трактора } \\
\text { Т-74 }\end{array}$ \\
\hline & & 043 & $\begin{array}{l}\text { 3мішування, } \\
\text { подрібнення } \\
\text { сировини } \\
\text { та формування } \\
\text { бурту } \\
\end{array}$ & $\begin{array}{l}\text { МТ3-80 з ходозменшувачем + } \\
\text { аератор - змішувач Продуктивність } \\
300-500 \text { м/год } \mathrm{Vp} \approx 0,3-0,5 \text { км/год }\end{array}$ \\
\hline \multirow{13}{*}{06} & \multirow{13}{*}{$\begin{array}{l}\text { Контроль за } \\
\text { процесами } \\
\text { компостування }\end{array}$} & 061 & $\begin{array}{l}\text { Механічне } \\
\text { перелопачування }\end{array}$ & $\begin{array}{l}\text { МТ3-80 } 3 \text { ходозменшувачем + } \\
\text { аератор-змішувач. За умови } \\
\text { підвищення температури в бурті } \\
\text { більше } 50 \quad{ }^{\circ} \text { С. Продуктивність - } \\
\text { більше } 300-500 \text { т/год. }\end{array}$ \\
\hline & & 062 & $\begin{array}{l}\text { 2-ге механічне } \\
\text { перелопачування }\end{array}$ & $\begin{array}{l}\text { Проводиться через } 10 \ldots 14 \text { днів } \\
\text { після попереднього змішування. }\end{array}$ \\
\hline & & 0621 & Зволоження & \\
\hline & & 06211 & $\begin{array}{l}\text { Заправка ємності } \\
\text { з рідиною }\end{array}$ & $\begin{array}{l}\text { Трактор МТЗ-80 + ємність } 4 \text { м }^{3}+ \\
\text { водяний насос Об'єм рідини(води) - } \\
1-5 \% \text { від об'єму бурту } \\
\text { Продуктивність насосу -до } 10 \mathrm{~m}^{3} / \Gamma .\end{array}$ \\
\hline & & 06212 & Транспортування & $\begin{array}{l}\text { Трактор МТЗ-80+ємність } 4 \mathrm{M}^{3} \text {. } \\
\text { Дальність перевезень до 2км }\end{array}$ \\
\hline & & 062213 & Внесення рідини & $\begin{array}{l}\text { Трактор } \\
\text { змішувач. }\end{array}$ \\
\hline & & 062 & Перелопачування & $\begin{array}{l}\text { МТЗ- } 80+\text { аератор - змішувач } \mathrm{H}_{\text {бурту }} \\
=1,1 \text { м. } \text { Вурту }_{\text {бо }} 2,5 \mathrm{M} . \mathrm{L}_{\text {бурту }}-\text { до } \\
50 \text { м. }\end{array}$ \\
\hline & & 063 & $\begin{array}{l}\text { 3-е механічне } \\
\text { перелопачування }\end{array}$ & $\begin{array}{l}\text { Через 7-10днів після попереднього } \\
\text { змішування. }\end{array}$ \\
\hline & & 0631 & Зволоження & $\begin{array}{l}\text { Трактор МТ3-80+ємність } 4 \text { м }^{3} . \\
\text { Рідини (води) }-1-5 \% \\
\end{array}$ \\
\hline & & 06311 & $\begin{array}{l}\text { Заправка ємності } \\
\text { рідиною }\end{array}$ & 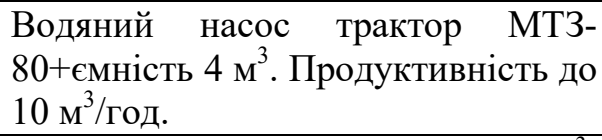 \\
\hline & & 06312 & Транспортування & $\begin{array}{lll}\text { Трактор } & \text { МТЗ-80+ємність } 4 & \text { м }^{3} . \\
\text { Дальність перевезень до 2 км. } & \\
\end{array}$ \\
\hline & & 0613 & Внесення рідини & $\begin{array}{l}\text { Трактор } \\
\text { змішувач. }\end{array}$ \\
\hline & & 063 & Перелопачування & $\begin{array}{l}\mathrm{H}_{\text {бурту }}=0,9 \mathrm{~m}, \mathrm{~B}_{\text {бурту }}=25 \mathrm{M} \text { до } 2,5 \mathrm{M}, \\
\mathrm{L}_{\text {бурту }}=\text { до } 50 \mathrm{M} .\end{array}$ \\
\hline 07 & Готовність & & & За 2 місяці \\
\hline \multirow[t]{2}{*}{08} & $\begin{array}{l}\text { Внесення } \\
\text { добрив }\end{array}$ & 081 & Навантаження & \begin{tabular}{lcr} 
Навантажувач & «Карпатець» & 3 \\
грейферним & \multicolumn{2}{c}{ захватом. } \\
Продуктивність до 25 т/год
\end{tabular} \\
\hline & & 082 & Внесення добрив & $\begin{array}{l}\text { Трактор МТЗ-80+ПРТ 7(ПРТ-10) } \\
\text { Дальність перевезення до } 5 \text { км. }\end{array}$ \\
\hline
\end{tabular}


За 10-15 діб сформовано бурти підстилкового гною, що викладувались послідовно вивантаженням рядами. Висота буртів складала 0,4-1,0 м. Через недостатню кількості підстилкового матеріалу сировина розтікалась до ширини 3-4 м, а висота 0,2-0,8 м. На базі трактора Т-74 з бульдозерним обладнанням збільшувались бурти. Параметри бурту (табл. 3), сформовані бульдозером показують значні відхилення від рівномірності. Загальна довжина бурту до 50 м. Обробку бурту трактором МТ3-80, обладнаним ходозменшувачем 3 аератором-змішувачем проводили 3 виділенням ділянки бурту в 30 м на якій обліковувався час обробки, вимірювались параметри бурту, щільність сировини, вологість і показники NPK, відносно яких розраховувались показники, представлені в табл. 3 і 4.

Таблиця 3 - Основні параметри бурту

\begin{tabular}{|c|c|c|c|c|c|}
\hline Показники & \multicolumn{5}{|c|}{ Значення показників } \\
\hline Технічний засіб & \multirow{2}{*}{\begin{tabular}{|c|}
$\begin{array}{c}\text { Бульдозер } \\
\text { трактор T-74 }\end{array}$ \\
18.06 .15
\end{tabular}} & \multicolumn{4}{|c|}{$\begin{array}{c}\text { Трактор МТЗ-80 з ходозменшувачем + } \\
\text { аератор-змішувач конструкції } \\
\text { IМТ НААН }\end{array}$} \\
\hline $\begin{array}{l}\text { Дата проведення } \\
\text { випробування }\end{array}$ & & 07.07 .15 & 22.07 .15 & 05.08 .15 & 20.08 .15 \\
\hline $\begin{array}{l}\text { Щільність } \\
\text { сировини*, кг/м3 }\end{array}$ & 890 & 789 & 759 & 739 & 768 \\
\hline \multicolumn{6}{|l|}{ Параметри бурту, м } \\
\hline Довжина: загальна & 50 & 50 & 50 & 50 & 50 \\
\hline залікова & & 30 & 30 & 30 & 30 \\
\hline ширина & 2,4 & 2,2 & 2,1 & 2,5 & 2,5 \\
\hline висота & $0,6-1,1$ & 0,76 & 0,68 & 0,60 & 0,55 \\
\hline Переріз бурту, м $^{2}$ & 1,02 & 0,836 & 0,816 & 0,75 & 0,69 \\
\hline Об'єм бурту, м ${ }^{3}$ & 30,6 & 25,08 & 24,58 & 22,5 & 20,7 \\
\hline Маса бурту, т & 27,23 & 19,8 & 18,6 & 16,6 & 15,9 \\
\hline
\end{tabular}

*Щільність сировини - 692 кг/м3 на 03.06.2015

Друга і третя обробка проводилась за тих же умов. Після кожної обробки в бурт установлювався зонд, який вимірював зменшення висоти бурту між аераціями (табл.4).

Таблиця 4 - Основні результати випробування технічних засобів механізованої технології компостування

\begin{tabular}{|c|c|c|c|c|c|}
\hline \multirow{2}{*}{ Назва операції } & \multirow{2}{*}{$\begin{array}{c}\text { Попереднє } \\
\text { формування } \\
\text { бурту }\end{array}$} & \multicolumn{3}{|c|}{ перелопачування } & \multirow{2}{*}{$\begin{array}{c}\text { Закінчення } \\
\text { циклу }\end{array}$} \\
\hline & & $\mathrm{I}$ & II & III & \\
\hline $\begin{array}{l}\text { Маса бурту на } 1 \text { метр } \\
\text { довжини, т/M* }\end{array}$ & - & 0,66 & 0,62 & 0,55 & - \\
\hline Робоча швидкість, м/с & 0,5 & 0,110 & 0,150 & 0,21 & - \\
\hline $\begin{array}{ll}\text { Пропускна } & \text { здатність } \\
\text { аератора, кг/с } & \end{array}$ & - & 69,7 & 96,3 & 136,2 & - \\
\hline Продуктивність, т/год & - & 250,1 & 346 & 490,4 & - \\
\hline $\begin{array}{l}\text { Просідання висоти бурту } \\
\text { між обробками, мм }\end{array}$ & - & 50 & 40 & 40 & 60 \\
\hline $\begin{array}{l}\text { Температура в середині } \\
\text { бурту, } \mathrm{T}^{\circ} \mathrm{C}\end{array}$ & - & 35 & 30 & 28 & 25 \\
\hline
\end{tabular}

** Розрахункові показники 
Основні ознаки готового компосту: органічна маса повинна бути рівномірно ферментована; одержаний продукт (компост) розсипчастий і має темно бурий (чорний) колір; відсутність запахів, солома втратила свій стан, стала крихкою.

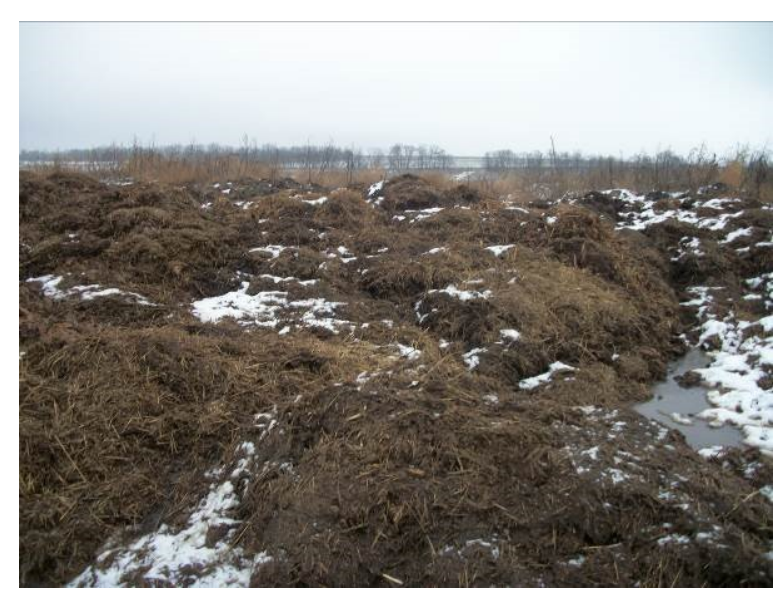

б) Суцільне укладання гною

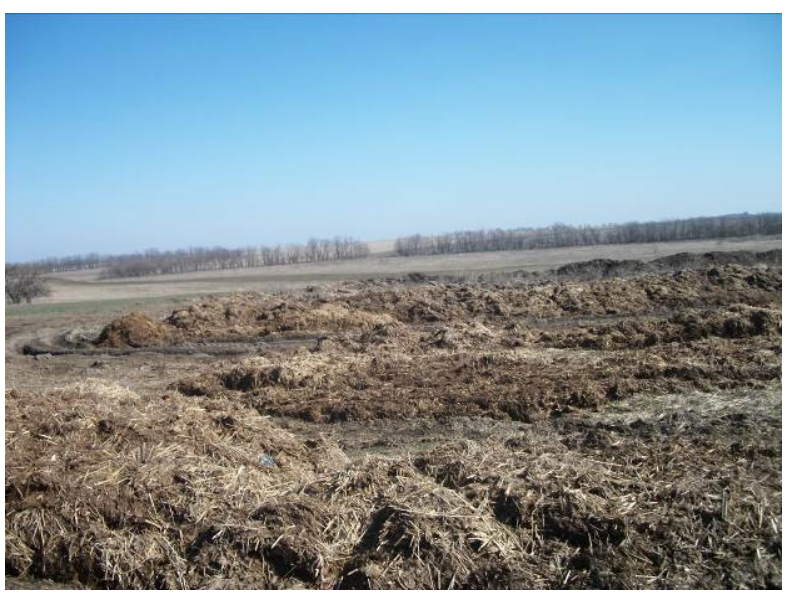

в) Формування буртів при вивантаженні сировини

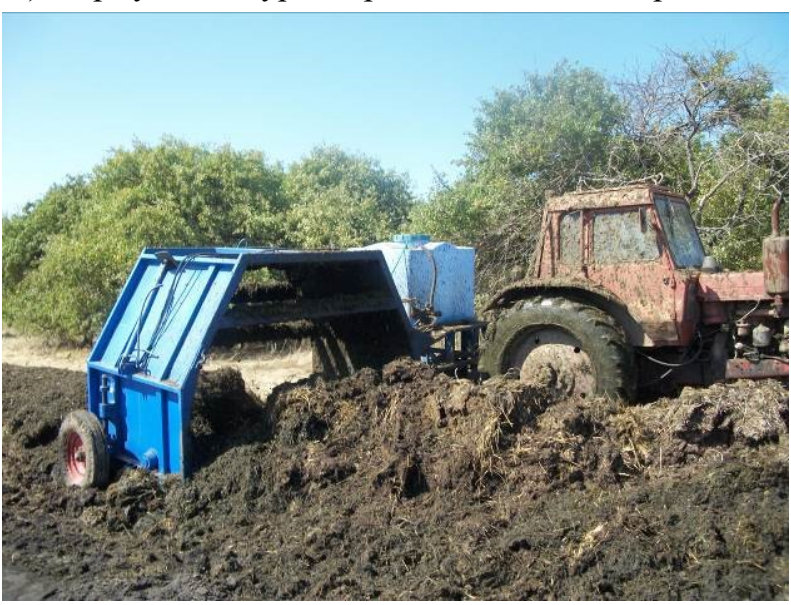

д) Формування буртів агрегатом МТЗ-80 3 ходозменшувачем та аератором-змішувачем 3 одночасним подрібненням та змішуванням сировини

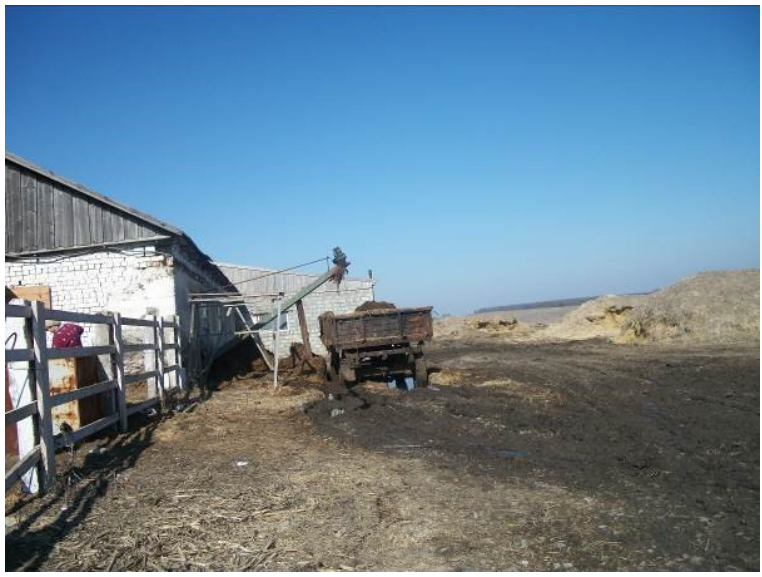

а) Вивантаження гною 3 тваринницького приміщення

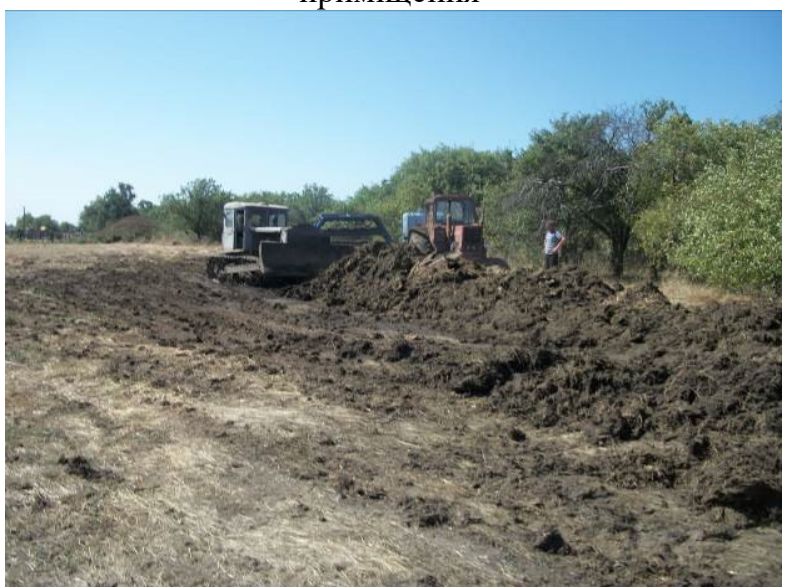

г) Укрупнення буртів бульдозерним обладнанням

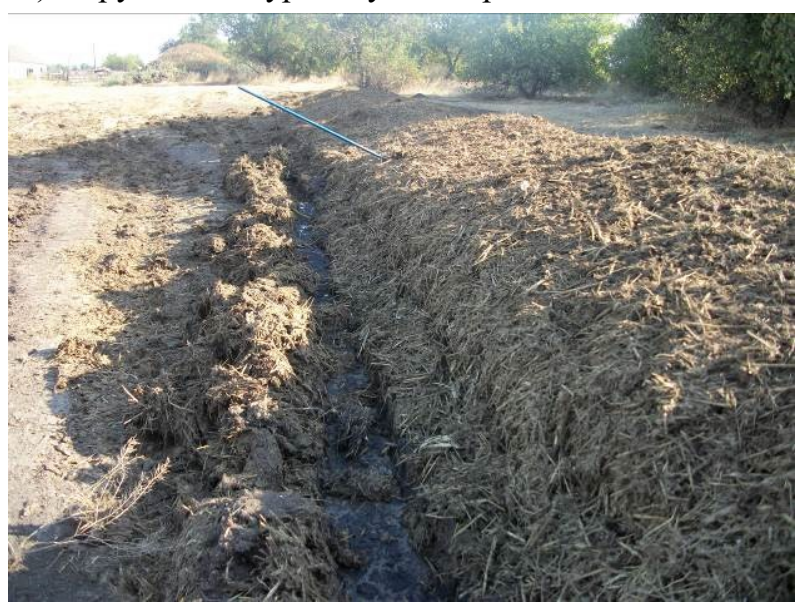

е) Вигляд бурта після першого проходу агрегату

Рисунок 2 - Загальний вигляд виробничого випробування технології механізованого компостування органічних відходів з використанням аератора-змішувача 
Результати дослідження i їx аналіз. Згідно поставлених задач і прийнятих робочих гіпотез вдосконалення технологічного процесу (рис. 2) поводження 3 органічними відходами ферми великої рогатої худоби одержані наступні результати.

При суцільному укладанні сировини висота шару підстилкового гною складає 0,5-1,0 м., формування проходів для проходу аератора-змішувача 3 допомогою грейферного навантажувача «Карпатець» характеризується продуктивністю до 20-25 т/год. Умови переміщення агрегату в проходах із-за високої вологості поверхні не дозволяють виконувати їх ефективно. Формування проходів в суцільному середовищі підстилкового гною за допомогою бульдозерної навіски на трактор Т-74 теж складаються проблемними. Для підготовки до роботи аератора-змішувача сировини попередньо вивантажували послідовно розміщеними кучами, формуючи бурт висотою 0,5-0,8 м. Через недостатню масу підстилкового матеріалу гній розтікався до висоти 0,2-0,4 м., а для укрупнення буртів використовувався бульдозер на базі трактора Т-74. Недолік процесу укрупнення буртів - ущільнення сировини при виконанні робочого процесу бульдозером, нерівномірна висота бурту, що в подальшому впливає на роботу агрегату з аератором.

1. Технологічний комплекс 3 проведення прискореного компостування 3 використанням аератора-змішувача підстилкового гною великої рогатої худоби забезпечує скорочення термін компостування органічної сировини до 45-60 діб.

2. Конструкція аератора-змішувача забезпечує якісне змішування гною великої рогатої худоби 3 підстилковим матеріалом - соломою. Формування буртів після проходу агрегату рівномірно по висоті та ширині. Від проходу до проходу змінюється агрегатний стан сировини - зменшуються розміри часток, формуються нові агрегатні стани, що близькі до грунтових до кінця терміну обробки. Структура готового компосту характеризується однорідним розміром часток, 10-20 мм.

3. Температурні режими компостування відповідають мезофіль-ному процесу і температура складає $28-35^{\circ} \mathrm{C}$.

4. Енергозасіб. Трактор МТЗ-80 з ходозменшувачем. Робочі швидкості - 0,100,25 м/с. Навантаження на енергозасіб налаштовується зміною швидкісного режиму. Продуктивність аератора від 300 до 500 т/год. Менші при формуванні буртів - першого проходу із-за нерівномірного навантаження - більші при послідуючих проходах на буртах.

Температура субстрату за час спостереження не перевищувала 25-40 , що відповідає мезофільному температурному процесу. Досягти температур, що відповідають умовам термофільності (T $\left.>55^{\circ}\right)$ процесу компостування не склалось із-за невідповідності співвідношення $\mathrm{C}: \mathrm{N}=25 \pm 5: 1$ (факт 16,0:1), висота буртів менше $1 \mathrm{M}$, що не забезпечує відповідні умови для активізації мікроорганізмів.

Визначалась контролем за температурою в бурту, її стабіл-ізацією на протязі 3-5 діб і поступовим зменшенням температури.

\section{Висновки.}

1. Розроблена механізована технологія компостування для умов господарства забезпечує одержання високоефективних добрив за 45-60 діб, що значно зменшує термін природного компостування.

2. Використання аератора-змішувача для змішування i аерації на сировині

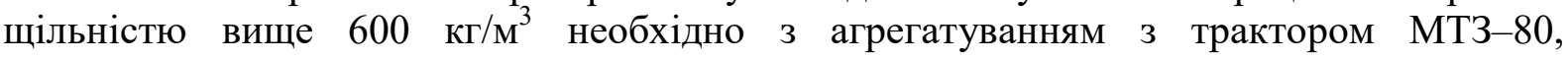
обладнаним ходозменшувачем, що забезпечують робочу швидкість від $0,1 \mathrm{~m} / \mathrm{c}$ і вище. Продуктивність аератора-змішувача при цьому складає 300-500 т/год.

3. Для підвищення технологічних i експлуатаційних показників при компостуванні з використанням аератора-змішувача доцільно попереднє формування буртів по висоті і ширині, що і забезпечує рівномірне завантаження енергозасобу, яке 
характеризується масою сировини бурту і складає до 1000кг/м для даного типу технічного засобу.

4. Технологічний прийом аерації позитивно впливає на збільшення складових агрохімічного складу компосту і збільшується на 20-30 \%.

\section{Список літератури}

1. ВНТП-АПК-09.06 Відомчі норми технологічного проектування. Системи видалення, обробки, підготовки та використання гною / - К.: Мінагрополітики України, 2006. - 100 с.

2. ВНТП-АПК-04.05 Відомчі норми технологічного проектування. Птахівницькі підприємства / - К.: Мінагрополітики України, 2006. - 90 с.

3. ВНТП-АПК-01.05 Відомчі норми технологічного проектування. Скотарські підприємства. (комплекси, ферми, малі ферми) / - К.: Мінагрополітики України, 2005. - 111 с.

4. Павленко С.И. Технологические решения переработки навоза на животноводческих предприятиях [Текст] / С.И. Павленко, А.А. Ляшенко // Вестник ВНИИМЖ. Ежеквартальный научный журнал. Серия: Механизация, автоматизация и машиные технологии в животноводстве. - $\mathrm{M}$ : ГНУВНИИМЖ. - 2013. - Вып. №4(12). - С.114-121.

5. Обгрунтувати перспективні напрямки і технологічні схеми виробництва органо-мінеральних добив шляхом компостування: Звіт про НДР в УкрIHТЕІ/Ін-т мех. тварин. УААН; № ДР 0101U007033; Інв.0302U001868, Запоріжжя, 2002. - 47 c.

6. Павленко С.І. Обгрунтування технологічної схеми процесу компостування органічних відходів на відкритих майданчиках [Текст] / С.І. Павленко // Вісник ХНТУСГ ім. П.Василенко, «Технічні системи і технології тваринництва» . - 2015. - Вип. 157 - С. 197-201.

7. Шевченко I.А. Результати експериментальних досліджень змішувача-аератора компостів [Текст] / I.А. Шевченко, В.І. Харитонов, Е.В. Аліев // Механізація, екологізація та конвертація біосировини у тваринництві . Збірник наукових праць Інституту механізації тваринництва НААН України. 2011 . - Вип. 2(8). - С. 80-88.

8. Павленко С.І. Новітні технічні засоби переробки органічних відходів [Текст] / С.І. Павленко, О.О. Ляшенко, А.А. Поволоцький, Ю.А. Філоненко // Вісник ХНТУСГ ім. П.Василенка «Технічні системи і технології тваринництва». - 2013. - Вип. 132. - С.193-200.

9. Павленко С.І. Експериментальні дослідження процесу біоконверсного компостування пташиного посліду [Текст] / Павленко С.І., Ляшенко О.О., Філоненко Ю.А. // Науковий вісник Національного університету біоресурсів і природокористування України. Серія: Техніка і енергетика АПК. - 2014 .- Вип. 196. - 4.1. - С. 400-409

10. Павленко С.И. Результаты производственных испытаний смесителя-вератора компостов [Текст] / С.И. Павленко, А.А. Ляшенко // Научно-технический прогресс в сельскохозяйственном производстве: материалы Междунар. науч.-техн. конф.: в 2 т. / РУП «НПЦ НАН Беларуси по механизациисельскогохозяйства». - Минск, 2015. - Т. 1. - С. 148-153.

\section{Referencis}

1. VNTP-APK-09.06 Vidomchi normy tekhnolohichnoho proektuvannia. (2006). Systemy vydalennia, obrobky, pidhotovky ta vykorystannia hnoiu. Kyiv.: Minahropolityky Ukrainy.

2. VNTP-APK-04.05 Vidomchi normy tekhnolohichnoho proektuvannia. (2006). Ptakhivnyts'ki pidpryiemstva. Kyiv: Minahropolityky Ukrainy.

3. VNTP-APK-01.05 Vidomchi normy tekhnolohichnoho proektuvannia. (2005). Skotars'ki pidpryiemstva. (kompleksy, fermy, mali fermy). Kyiv: Minahropolityky Ukrainy.

4. Pavlenko, S.I. \& Ljashenko, A.A. (2013). Tehnologicheskie reshenija pererabotki navoza na zhivotnovodcheskih predprijatijah [Technological solutions for manure processing in livestock enterprises]. Vestnik VNIIMZh. Ezhekvartal'nijnauchnij zhurnal. Serija: Mehanizacija, avtomatizacija i mashinnyetehnologii $v$ zhivotnovodstve - Journal of VNIIMZH. Quarterly scientific journal. Series: Mechanization, Automation and Machine Technologies in Livestock, Vol. №4(12), 114-121.

5. To substantiate the perspective directions and technological schemes of production of organo-minerals made by composting. (2002). Zvit pro NDR v UkrINTEI/In-t mekh. tvaryn. UAAN; № DR 0101U007033; Inv.0302U001868, Zaporizhzhia, 47.

6. Pavlenko, S.I. (2015). Obhruntuvannia tekhnolohichnoi skhemy protsesu kompostuvannia orhanichnykh vidkhodiv na vidkrytykh majdanchykakh [Justification of the technological scheme of the process composting of organic waste in open areas]. Visnyk KhNTUSH im. P.Vasylenko, «Tekhnichni systemy $i$ tekhnolohii tvarynnytstva» - Bulletin KNTUA P.Vasilenko, "Technical systems and technologies of animal husbandry", Vol. 157, 197-201. 
7. Shevchenko, I.A., Kharytonov, V.I. \& Aliev, E.V. (2011). Rezul'taty eksperymental'nykh doslidzhen' zmishuvacha-aeratora kompostiv [Results of experimental studies of the mixer-aerator of compost]. Mekhanizatsiia, ekolohizatsiia ta konvertatsiia biosyrovyny u tvarynnytstvi // Zbirnyk naukovykh prats' Instytutu mekhanizatsii tvarynnytstva NAAN Ukrainy - "Mechanization, greening and convert biosyrovyny in cattle". Scientific magazine NSC "Institute of agriculture NAAS" Vyp. 2(8). Zaporizhzhia: IMT NAAN, $2011-$ S. 80-88

8. Pavlenko, S.I., Liashenko, O.O., Povolots'kyj, A.A. \& Filonenko, Yu.A. (2013). Novitni tekhnichni zasoby pererobky orhanichnykh vidkhodiv [The latest technical equipment for the recycling of organic waste]. Visnyk KhNTUSH im. P.Vasylenka «Tekhnichni systemy i tekhnolohii tvarynnytstva» - Bulletin KNTUA P.Vasilenko, "Technical systems and technologies of animal husbandry", Vol. 132, 193-200

9. Pavlenko, S.I., Liashenko, O.O. \& Filonenko, Yu.A. (2014). Eksperymental'ni doslidzhennia protsesu biokonversnoho kompostuvannia ptashynoho poslidu [Experimental researches of process of biologicalconversion composting of poultry manure]. Naukovyj visnyk Natsional'noho universytetu bioresursiv i pryrodokorystuvannia Ukrainy. Seriia: Tekhnika i enerhetyka APK - Scientific Herald of NULES of Ukraine. Series: Technique and energy of APK, Vol. 196, 4.1, 400-409.

10. Pavlenko, S.I. \& Ljashenko, A.A. (2015) Rezul'taty proizvodstvennyh ispytanij smesitelja-veratora kompostov [The results of the production tests of the mixer-vertector compost]. Scientific and technological progress in agricultural production: Mezhdunarodnaia nauchno-tehnicheskaia konferenciia - Intenational Scientific and technical Conference. (pp. 148-153) (Vols.2; Vol.1). Minsk: RUP «NPC NAN Belarusi po mehanizaciisel'skogohozjajstva».

Sergiy Pavlenko, Assoc. Prof., PhD tech. sci., Senior Researcher

National University of Life and Environmental Sciences of Ukraine, Kiev, Ukraine

\section{Industrial Testing OF Technology Mechanized Composition of Organic Wastes With the Use of Aerator-Mixernull}

Adaptation of new technological methods and technical means of mechanized composting of organic waste of bovine cattle at steady maintenance and daily disposal of organic waste requires systemic solutions based on the analysis of organizational and economic conditions. In practical terms, it is necessary to prove the feasibility of introducing modern solutions: technologies, technical means, methods of use before existing in the economy. The purpose of the further development of rational use of technical means in the mechanized processes of solid phase composting.

A systematic analysis of the management of organic waste, existing in the farm on the cattle stockholding system, was carried out. The results of the analysis are summarized in the form of a table that deals with the technological process, operations and the composition of the technical means and materials and the value of the indicators of the operation. Worked hypotheses for improving the technology of handling organic waste based on the improvement of technological techniques of the cycle, which need to conduct an experimental verification:

- the formation of bursts in the continuous storage of gnawing mixtures due to the creation of passages with a width of up to $2-3 \mathrm{~m}$ in the medium of raw materials up to $75 \%$ humidity using a bulldozer or other technical means;

- formation of bursts during unloading of gnoyeposobnoy mixture at the site during transportation of raw material by a dumper tractor trailer or spreader of organic fertilizers that are aggregated with a tractor MTZ-80;

- consolidation of bursts using a bulldozer;

- Improvement of aeration due to the use of an aerator-mixer, the structure of the IMT NAAS of Ukraine.

Improved technological and technical regulations for mechanized composting have been developed. The geometric parameters of the drums, their density, mass are determined. The results of testing the technical equipment: bulldozer, mixer aerator according to standard methods are carried out.

Main conclusions. Formation of passages in the raw material, which is enclosed entirely with the help of a bulldozer, is not efficient. Previously, it is necessary to form bursts when unloading in a row.

The technological complex of technical means ensures high-quality mixing, formation of drills in height and width, new aggregates are created - the size of particles close to the soil aggregates.

The cycle is up to 45-60 days.

Productivity of the unit: tractor MTZ-80 with throttle reducer from 300 to $500 \mathrm{t} /$ year. Smaller values at first passages. Working speeds $0,10-0,25 \mathrm{~m} / \mathrm{s}$. Technological operations of accelerated composting can increase the chemical composition of organic fertilizers by $20-30 \%$, reduce the loss of nutrients, increase the mass of organic fertilizers, introduced on the field by $60-70 \%$.

production tests, technology, compost, accelerated composting, aerator-mixer, burt formation 